\title{
Н. Максіменцева,
}

професор кафедри теорії держави і права, конституційного права

та державного управління

Дніпровського національного університету імені Олеся Гончара

\section{МІЖНАРОДНІ ТА ЄВРОПЕЙСЬКІ СТАНДАРТИ ПІД ЧАС ДОСУДОВОГО РОЗСЛІДУВАННЯ КРИМІНАЛЬНИХ ПРАВОПОРУШЕНЬ, ПОВ'ЯЗАНИХ IЗ ЗАСТОСУВАННЯМ КАТУВАНЬ ТА ІНШОГО ЖОРСТОКОГО ПОВОДЖЕННЯ 3 ЛЮДЬМИ, ВЧИНЕНИХ ПРАЦІВНИКАМИ ПРАВООХОРОННИХ ОРГАНІВ}

Україна як одна з країн Організації Об'єднаних Націй (далі - ООН), Ради Європи гарантує кожному захист загальновизнаних i основоположних прав і свобод людини та громадянина.

Конституцією України людина, ii життя і здоров'я, честь і гідність, недоторканність і безпека визнаються найвищою соціальною цінністю [1]. Утвердження i забезпечення прав і свобод людини $є$ головним обов'язком держави. Відповідно до ст.ст. 28, 29 Основного Закону кожній людині гарантується право на повагу іiі гідності, свободу та особисту недоторканність.

Міжнародні нормативно-правові акти, які ратифіковано у встановленому порядку і які, відповідно до положень ст. 9 Конституції України, $€$ частиною національного законодавства, також встановлюють сувору заборону щодо вказаних дій.

Так, ст. 3 Конвенції проти катувань та інших жорстоких, нелюдських або таких, що принижують гідність, поводжень чи покарань від 10.12.1984 р. [2] (далі - Конвенція), яку ратифіковано указом Президії Верховної Ради Української РСР від 06.01.1987 р. [3], визначає, що жодна людина не може бути піддана катуванню або нелюдському чи такому, що принижує гідність, поводженню або покаранню. Вказана норма встановлює безумовну заборону катувань, нелюдського чи такого, що принижує гідність, поводження й покарання.

Абсолютна заборона катування $€$ імперативною нормою міжнародного права і закріплена в усіх основних міжнародних нормативно-правових актах, починаючи від загальних принципів міжнародного права, міжнародних документів звичаєвого права і закінчуючи міжнародними договорами.

Проте досить часто такими правами нехтують, їх свавільно порушують, у тому числі, працівники правоохоронних органів, які за змістом поняття «правоохоронні органи» фактично мають охороняти права і свободи людини і громадянина.

Так, відповідно до Сьомого періодичного звіту, поданого Україною на виконання положень ст. 19 Конвенції проти катувань та інших жорстоких, нелюдських або таких, що принижують гідність, поводжень чи покарань від 11.02.2019 р. за 9 місяців 2018 р. порушено 73,563 кримінальних провадження щодо катувань та жорстокого поводження, скоєних працівниками правоохоронних органів. За результатами розслідування було складено 27 обвинувальних актів проти 47 осіб. 2 обвинувальних акти щодо загальної кількості було подано щодо катувань, 23 - за неналежне здійснення 
службових повноважень правоохоронцем та 2 - за іншими звинуваченнями відповідно. Вищезазначені звинувачення стосуються 46 співробітників міліції та 1 особи з державної кримінально-виконавчої служби [4].

Враховуючи досить велику кількість кримінальних проваджень щодо катувань та жорстокого поводження, скоєних працівниками правоохоронних органів, доцільно визначити особливості здійснення процесуального керівництва за вказаними справами, а саме щодо застосування міжнародних та європейські стандартів, національного законодавства.

Такі міжнародні та європейські стандарти, що містяться в нормативно-правових актах щодо встановлення вимог та заборон стосовно катування та іншого жорстокого поводження з людьми можна поділити за сферою застосування: загальні (міжнародні, прийняті $\mathrm{OOH}$, які ратифікуються членами цієї міжнародної організації, тобто мають широке коло суб'єктів ратифікаціï) та територіальні (регулюють правовідносини держав окремо визначеної територіальної спільноти) - обмежені за колом суб'єктів i територією регулювання. Так, до актів загального регулювання можна зарахувати такі: Загальна декларація прав людини 1948 р. (ст. 5), Міжнародний пакт про громадянські та політичні права 1966 р. (п. 2 ст. 4, ст. 7, ст. 10), Додаткова конвенція про скасування рабства, работоргівлі і інститутів і звичаїв, подібних до рабства 1956 р. (ст. 5), Конвенція про права дитини 1989 р. (ст. 19, ст. 37 та ін.), Конвенція проти катувань та інших жорстоких, нелюдських або принижуючих гідність видів поводження і покарання 1984 р.

Своєю чергою актами територіального регулювання можна визнати такі: Конвенція про захист прав людини й основоположних свобод 1950 р. (ст. 3); Європейська конвенція про запобігання катуванням чи нелюдському або такому, що принижує гідність, поводженню чи покаранню 1987 р. і два протокола до неї; Американська конвенція про права людини 1969 р. (ст. 5); Арабська хартія прав людини 2004 р. (ст. 8); Африканська хартія прав людини i народів 1981 р.(ст. 5) та інші. Україна ратифікувала майже всі міжнародні та європейські регіональні міжнародні угоди, що стосуються заборони катувань.

Отже, які безпосередньо дії можуть кваліфікуватись як «катування» у вказаних міжнародних нормативно-правових актах, як вони співвідносяться із національними нормативними актами?

Так. ст. 1 Конвенції ОО «Проти катувань та інших жорстоких, нелюдських або таких, що принижують гідність, поводжень чи покарань» визначає поняття «катування» як будь-яку дію, якою будь-якій особі навмисне заподіюються сильний біль або страждання, фізичне чи моральне, щоб отримати від неї або від третьої особи відомості чи визнання, покарати іï за діï, які вчинила вона або третя особа чи у вчиненні яких вона підозрюється, а також залякати чи примусити іiі або третю особу, чи з будь-якої причини, що грунтується на дискримінації будьякого виду, коли такий біль або страждання заподіюються державними посадовими особами чи іншими особами, які виступають як офіційні, чи 3 їх підбурювання, чи з ї відома, чи за їхньої мовчазної згоди. У цей термін не включаються біль або страждання, що виникли внаслідок лише законних санкцій, невіддільні від цих санкцій чи спричиняються ними випадково» [5].

Своєю чергою Європейська конвенція про запобігання катуванням чи нелюдському або такому, що принижує гідність, поводженню чи покаранню від 26.11.1987 р. не визначає поняття «катування», проте створює Європейський комітет із питань запобігання катування чи нелюдського або такого, що принижує гідність, поводження чи покарання [6]. Рекомендації Комітету є одними з керівних засад під час досудового слідства. 
Національне законодавство своєю чергою у ст. 127 Кримінального кодексу України (далі КК України) визначає поняття «катування» як умисне заподіяння сильного фізичного болю або фізичного чи морального страждання шляхом нанесення побоїв, мучення або інших насильницьких дій із метою примусити потерпілого чи іншу особу вчинити діï, що суперечать їх волі, у тому числі отримати від нього або іншої особи відомості чи визнання, або з метою покарати його чи іншу особу за дії, скоєні ним або іншою особою чи в скоєнні яких він або інша особа підозрюється, а також із метою залякування чи дискримінації його або інших осіб [7].

Отже, характерними ознаками кваліфікації за ст. 127 KK України є суб'єктивна сторона - умисність діяння, об'єктивна сторона - заподіяння фізичного болю. Проте, на відміну від міжнародно-правового визначення поняття «катування», де зазначено особливий вид суб'єктів - державні посадові особи чи інші особи, які виступають як офіційні, у чинному KK України жодним чином не виокремлено таких суб'єктів злочину.

Звернемо увагу, що проектом Закону «Про внесення змін до деяких законодавчих актів України щодо забезпечення гармонізації кримінального законодавства 3 положеннями міжнародного права» запропоновано викласти ст. 127 KK України у такій редакції, де закріпити поняття «катування» як «жорстоке, нелюдське чи таке, що принижує гідність, поводження 3 людиною, яке полягає в умисному заподіянні їй шляхом дії або бездіяльності сильного фізичного чи морального страждання або болю», у ч. 4 визначено вчинення такого саме діяння представником влади, особою, що перебуває на державній службі в Україні, посадовою особою іноземної держави або особою, яка незаконно здійснює владні чи управлінські функціï на тимчасово окупованій території України, з використанням влади чи службового становища, або вчинене іншою особою, яка діє з підбурювання, з відома чи за мовчазної згоди однієї із зазначених осіб, та встановлено більш суворе покарання шляхом позбавлення волі на строк від семи до дванадцяти років [8].

Розслідування фактів катування, жорстокого, нелюдського або такого, що принижує людську гідність, поводження чи покарання, вчинених правоохоронцями, зараховано до підслідності слідчих новоутвореного органу - Державного бюро розслідувань (ст. 5 Закону України «Про ДБР»).

Раніше такі порушення законності розслідувалися, як правило, слідчими органів прокуратури, також прокурорами здійснювався нагляд за досудовим розслідуванням. Проте міжнародні правові інституції систематично висловлювали зауваження щодо якості та ефективності досудового розслідування злочинів зазначеної категорії, а також щодо неможливості одночасно проводити розслідування та здійснювати нагляд за досудовим розслідуванням одним органом, що зумовлює брак об'єктивності, незалежності та неупередженості. Надалі в результаті проведеної реформи прокуратура втратила функцію досудового розслідування.

Водночас із року в рік Україна продовжує залишатися лідером серед країн Ради Європи, проти яких ЄСПЛ винесені судові рішення, в тому числі у зв'язку з порушенням ст. 3 Конвенції щодо заборони катувань. Відповідні рішення переважно стосуються фактів неналежної поведінки з боку державних службовців - працівників правоохоронних органів.

Основними стандартами, які мають використовуватися під час досудового розслідування в кримінальних провадженнях про злочини, пов'язані із застосуванням катувань та іншого жорстокого поводження 3 людьми, вчинені працівниками правоохоронних органів, є положення ст. 3 Конвенції та відповідна практика ЄСПЛ, рекомендації Європейського комітету 
з питань запобігання катуванням чи нелюдському або такому, що принижує гідність, поводженню чи покаранню (далі - Комісія) [9], Стамбульський протокол (Керівні принципи $\mathrm{OOH}$ із питань ефективного розслідування і документування фактів катувань та інших жорстоких i таких, що принижують гідність, видів поводження та покарання) [10].

Комісія акцентує увагу на аспектах, які мають забезпечити належне виявлення та фіксацію ознак катувань, а також своєчасне реагування на такі випадки. Серед таких напрямів можна визначити створення досьє кожного затриманого (т.зв. custody records), необхідність проведення медичного обстеження та інші.

Так, основні гарантіі, які надаються затриманим поліцією особам, будуть значно підсилені, якщо буде вестись єдине i повне досьє щодо кожної затриманої особи, де б фіксувалися всі аспекти, що пов'язані із затриманням особи, та мають бути відображені всі заходи, яких було вжито щодо затриманої особи (час, коли особу було позбавлено волі, та мотив(и) цього заходу; час, коли особу було поінформовано про іï права; фіксація ушкоджень, проявів душевних захворювань тощо; час, коли було сповіщено близьких/консула чи адвоката, а також час, коли вони відвідали затриману особу; час, коли було запропоновано їжу; час, коли проводився допит; час, коли особу було переведено до іншого закладу або звільнено тощо) [11].

В Україні впровадження «custody records» почалося з 2017 р., у 2018 р. система запрацювала в ізоляторі тимчасового тримання (далі - ITT) міст Дніпро, Херсон, Кропивницький та Сарни. У 2018 р. через зазначені ITT пройшло 4975 осіб, з яких 1115 були поміщені до ITT, як затримані за підозрою у вчиненні злочину. У червні 2019 р. на базі ITT № 1 в місті Дніпро відкрито перший в Україні тренінговий центр, головним завданням якого $€$ розвиток нових навичок роботи персоналу ITT Національної поліції України із затриманими особами завдяки впровадженню системи «custody records» [12].

За результатами успішного пілотування системи Custody Records в ізоляторах тимчасового тримання постала необхідність включити до системи також етап фактичного затримання, доставлення затриманих до відділів поліції та перебування у відділі поліції, адже за стандартами, затвердженими Європейським комітетом із питань запобігання катуванням, електронне досьє є одним з основних запобіжників порушення прав людини та необхідне на всіх етапах перебування людини під контролем поліції [13].

Ще одним напрямом рекомендацій ЄKЗК можна визнати необхідність проведення медичних обстежень затриманих осіб без присутності працівників поліції: такі обстеження мають проводитись у такий спосіб, щоб поліцейські службовці не могли чути, а за можливості, й спостерігати за таким обстеженням. Документ, що складається після медичного обстеження, має містити обов'язкові елементи:

а) виклад заяв, зроблених особою, які стосуються медичного обстеження (y тому числі власний опис його/їі стану здоров'я та будь-які твердження про жорстоке поводження);

b) повний виклад медичних висновків, заснованих на ретельному огляді;

c) зауваження медичного працівника за попередніми пунктами, де вказується, чи узгоджуються будь-які твердження заявника й об'єктивні медичні показники [14].

Відповідний документ має також містити результати додаткових проведених обстежень, докладні висновки спеціалізованих консультацій та опис лікування травм і проведення будьяких подальших процедур. Результати медичного обстеження у випадках травматичних ушкоджень мають бути записані у спеціальній формі, передбаченій для цієї мети, разом зі схемами тіла для відмічання травматичних ушко- 
джень. Такі схеми мають зберігатися в медичній картці ув'язненого. Також бажано сфотографувати травми, помістивши фотографії в медичну картку. Крім того, необхідно вести спеціальний реєстр травм, в який мають записуватися всі види ушкоджень [13].

Хоча тут треба зауважити, що досудове розслідування в кримінальних провадженнях цієї категорії $€$ доволі складним, оскільки слідчому і прокурору необхідно з'ясувати дійсну картину події в ситуації, коли $є$ певна протидія з боку співробітників правоохоронних органів, які, використовуючи свої знання та надану владу, намагаються i будуть намагатися приховати вчинене правопорушення та перешкодити встановленню істини.

Звернемо увагу, що існують певні особливості застосування європейських стандартів під час досудового розслідування в зоні проведення антитерористичної операції на сході Украіни та операції Об'єднаних сил. Так, Постановою Верховної Ради України від 21.05.2015 р. № 462-VIII «Про заяву Верховної Ради України «Про відступ України від окремих зобов'язань, визначених Міжнародним пактом про громадянські і політичні права та Конвенцією про захист прав людини і основоположних свобод» [15] прийнято рішення про відступ України від окремих зобов'язань, визначених Конвенцією, на період до повного припинення збройної агресії Російської Федерації. Цей нормативний акт не звільняє державу від відповідальності за недотримання основоположних прав, неможливість відступу від яких закріплено ст. 4 Пакту (право на життя, заборона катування, заборона рабства, незаконне позбавлення волі, принцип проти закону зворотної діiі, право на визнання правосуб'єктності, право на свободу думки, совісті та релігіі) та ст.15 Конвенції (право на життя, крім випадків смерті внаслідок правомірних воєнних дій, а також заборона катування, заборона рабства та заборона покарання без закону).
Отже, можна зробити висновок: по-перше, кримінальні правопорушення, що вчиняються правоохоронцями, завдають значної шкоди не лише авторитету правоохоронної системи, а й авторитету держави загалом; по-друге, доцільно узгодити положення ст. 127 KK України «Катування» та визначити як більш соціально загрожуючий склад кваліфікуючу ознаку щодо вчинення злочину вказаної категорії державними посадовими особами чи іншими особами, які виступають як офіційні; по-третє, відповідно до вимог Стамбульського протоколу варто більш активно поширювати досвід та запроваджувати створення досьє кожного затриманого (т.з. custody records), проводити медичне обстеження, яке також заносити в електронне досьє.

У зв'язку з цим актуальним є забезпечення ефективного досудового розслідування і процесуального керівництва в кримінальних провадженнях слідчих ДБР про катування та інше неналежне поводження з людьми, що вчинене правоохоронцями.

у статті висвітлено питання застосування міннародних та європейських стандартів під час досудового розслідування кримінальних правопорушень, пов'язаних із застосуванням катувань та іншого жорстокого поводження з людьми, вчинених працівниками правоохоронних органів.

Основна увага приділена дослідженню таких міжнародно-правових нормативних актів, як Конвениія проти катувань та інших жорстоких, нелюдських або таких, що принижують гідність, поводжень чи покарань, Европейська конвениія про запобігання катуванням чи нелюдському або такому, що принижує гідність, поводженню чи покаранню та протоколи до неї.

Встановлено недостатню урегульованість суб'єктного складу державних посадових осіб чи інших осіб, які виступають як офіційні, порівняно з міннародними нормами. 
Отже, запропоновано переглянути зміст ст. 127 Кримінального кодексу України щцодо кваліфікації злочину катування шодо уточнення та розширення суб'єктного складу щодо представника влади, особи, що перебуває на державній службі в Україні, посадовою особою іноземної держави або особою, яка незаконно здійснюе владні чи управлінські функціi на тимчасово окупованій територіі України, з використанням влади чи службового становища.

Крім того, досліджено Рекомендаuзії Європейського комітету з питань запобігання катуванням чи нелюдському або такому, щзо принижуе гіоність, поводженню чи покаранню та зроблено висновок про необхідність забезпечення наленного виявлення та фіксації ознак катувань, а також своєчасного реагування на такі випадки. Серед таких напрямів визначено створення досье кожного затриманого (m.з. custody records), проведення медичного обстеження та інші.

Звернено увагу на особливості здійснення досудового розслідування вказаної категорії на тимчасово окупованіü території.

Також доведено необхідність подальшої гармонізаціі кримінального законодавства з положеннями міжнародного права та використання міжнародних та європейських стандартів під час досудового розслідування вказаної категорії кримінальних правопорушень.

Ключові слова: досудове розслідування, кримінальне правопорушення, пов'язане із застосуванням катувань та іншого жорстокого поводження з людьми, працівники правоохоронних органів, міжнародні та європейські стандарти.

Maksimentseva N. International and European standards for pretrial investigation of criminal offenses related to the torture and other cruel treatment of persons committed by law enforcement officers

The article covers the application of International and European standards in the pre-trial investigation of criminal offenses related to torture and other cruel treatment committed by law enforcement officers.

The main focus is on the study of such international legal acts as the Convention against Torture and Other Cruel, Inhuman or Degrading Treatment or Punishment, the European Convention for the Prevention of Torture and Inhuman or Degrading Treatment or Punishment and the corresponding minutes to them.

Insufficient regulation of the composition of public servants or other persons acting in such performance, compared to International norms, is determined in the article. Therefore, it is proposed to review the contents of Art. 127 of the Criminal Code of Ukraine as regards the qualification of the crime of torture in order to clarify and expand the composition of an exercising power or public authority executive representative, public servant of Ukraine, foreign official or a person illegally exercising power or administrative functions on the temporarily occupied territory of Ukraine.

In addition, the Recommendations of the European Committee for the Prevention of Torture and Inhuman or Degrading Treatment or Punishment (CPT) have been examined and it is concluded that it is necessary to ensure the proper exposure and recording of signs of torture and to respond to such cases in a timely manner. Among such tasks the following are defined: the creation of a dossier for each detainee (so-called custody records), the need for medical examination and others.

Attention is paid to the peculiarities of the pre-trial investigation of the named category of criminal offense on the temporarily occupied territories.

It is also proved that there is the need for further harmonization of domestic criminal laws with the provisions of International laws and the use of International and European standards 
for the pre-trial investigation of this category of criminal offenses.

Key words: pre-trial investigation; criminal offenses related to the use of torture and other cruel treatment; law enforcement officers; International and European standards

\section{Література}

1. Конституція України від 28.06 .1996 p. URL: https: / / zakon.rada. gov.ua/laws/show/254\% D0\% BA/96$\%$ D0\% B2\% D1\%80\#Text

2. Конвенція проти катувань та інших жорстоких, нелюдських або таких, що принижують гідність, поводжень чи покарань віо 10.12.1984 p. URL: https://zakon.rada.gov.ua/laws / show/995_085\#Text

3. Указ Президіі Верховної Ради Української РCP від 06.01.1987 p. URL: https: / / zakon.rada.gov.ua / laws / show/3484-11\#Text

4. Сьомий періодичний звіт, поданий Україною на виконання положень ст. 19 Конвенції проти катувань та інших жорстоких, нелюдських або таких, що принижують гідність, поводжень чи покарань від 11.02.2019 p. URL: http: / / docstore.ohchr.org / SelfServices / FilesHandler.ashx?enc=

5. Конвенція проти катувань та інших жорстоких, нелюдських або таких, що принижують гідність, поводжень чи покарань від 10.12.1984 p. URL: https: / / zakon.rada.gov.ua/laws / show/995_085\#Text

6. Європейська конвенція про запобігання катуванням чи нелюдському або такому, що принижуе гідність, поводженню чи покаранню від 26.11.1987 URL: https: / / zakon.rada.gov. ua/laws/show/995_068\#Text

7. Кримінальний кодекс України від 05.04.2001 p. URL: https://zakon.rada. gov.ua/laws/show/2341-14\#Text

8. Проєкт Закону України «Про внесення змін до деяких законодавчих актів України щодо забезпечення гармонізації кримінального законодавства $з$ положеннями міжнародного права» віо 20.12.2018 p. URL: http: / / w1.c1.rada.gov.ua / pls / zweb2 / webproc4_1?pf3511=65266

9. Рекомендації Європейського комітету з питань запобігання катуванням чи нелюдському або такому, що принижуе гідність, поводженню чи покаpанню URL: https://wrw.coe.int/en/ web / cpt / about-the-cpt? p_p_id $=56_{-}$ INSTANCE_2sd8GRtnPW2B\& $p_{-} p_{-}$ lifecycle $=0 \& p_{-} p_{-}$state $=$normal $\& p_{-} p_{-}$ mode $=v i e w \& p \_p \_c o l \_i d=c o l u m n-4 \& p \_p \_c o l \_$ count $=1 \& \_56 \_I N S T A N C E \_2 s d 8 G R \operatorname{Rn} P W 2 B \_$ languageId $=u k \_U A$

10. Стамбульський протокол (Керівні приниипи ООН з питань ефективного розслідування $i$ документування фактів катувань та інших жорстоких і таких, що принижують гідність, видів поводження ma покарання URL: http: / / wrw.un.org. ua / images / documents / 4157 / Istanbul\% 20 Protocol\% 20in\% 20Ukrainian.pdf

11. Боротьба з безкарністю: витяг з 14-ої Загальної доповіді Європейського комітету з питань запобігання катуванням чи нелюдському або такому, що принижуе гідність, поводженню чи покаранню (КЗК), опубліковано 2004 року. URL: https:// rm.coe.int/16806cd08b

12. Як впровадження Custody Records змінить процедуру затримання? URL: https: / / rus.lb.ua/blog / custody_ records/469115_yak_vprovadzhennya_ custody_records.html

13. Стамбульський протокол від 09.09.1999 p. URL: http:// wwr.un.org. ua/images / documents / 4157 / Istanbul\% 20 Protocol\% 20in\% 20Ukrainian.pdf

14. Тримання під вартою співробітниками правоохоронних органів: витяг з Другої Загальної доповіді, Європейського комітету з питань запобігання катуваннам чи нелюдському або такому, що принижуе гідність, поводженню чи покаранню (КЗК), опубліковано 1992 року. URL: https: / / rm.coe.int / 16806cea2e

15. Про заяву Верховної Ради Украӥни «Про відступ України від окремих зобов'язань, визначених Міжнародним пактом про громадянські $i$ політичні права та Конвениією про захист прав людини $i$ основоположних свобод : Постанова Верховної Ради України від 21.05.2015 p. № 462-VIII. URL: https: / / zakon.rada.gov. ua/laws/show/462-19\#Text 